\title{
IMPLEMENTATION OF APPOINTMENT AND DISMISSAL OF OFFICERS IN DEPARTMENT OF POPULATION AND CIVIL REGISTRATION AT MUSI RAWAS UTARA REGENCY BASED ON THE MINISTER OF HOME AFFAIRS OF THE REPUBLIC OF INDONESIA REGULATION NUMBER 76 OF 2015
}

\author{
By : \\ Dwi Rahma Okta Wulandari, Amirizal, Amancik
}

\begin{abstract}
This study was aimed to analyze the mechanism for the appointment and the dismissal of officers in the Department of Population and Civil Registration at Muratara Regency based on Permendagri Number 76 of 2015, and the legality of the appointment and the dismissal of officers in the Department of Population and Civil Registration carried out by the Regent of Muratara Regency.The type of this research was normative that supported by interviews, using a statutory approach and research material sources of primary and secondary data which were collected through literature and field studies. The results of this study indicate that the mechanism for the appointment and the dismissal of officers in the Department of Population and Civil Registration at Muratara Regency is based on Permendagri Number 76 of 2015. The appointment and the dismissal of the Head of Department of Population and Civil Registration as a Primary High Officer Position in regency are under the authority of the Minister of Home Affairs, not the Regent. The regent is only authorized to make proposals for appointment (and dismissal) through the Governor and includes proposals for three names of candidates for appointment, then one of them be elected by the Minister, stipulated by a Ministerial Decree, and inaugurated. The appointment and the dismissal of officers in Disdukcapil carried out by the Regent of Muratara Regency is illegal, considering that the dismissal of the head of Disdukcapil Department (Kadisdukcapil) and his new appointment in 2016 was carried out by the Regent, not by the Minister. Besides, there are no reasons and considerations (including the proposal for the appointment of an official candidate) for the dismissal of the previous Kadisdukcapil as stipulated in Permendagri Number 76 of 2015.
\end{abstract}

Keywords: Department of Population and Civil Registration; Muratara Regency; Appointment and Dismissal of Officers 


\section{A. INTRODUCTION}

\section{Research Background}

The population administration field is one of the areas of government that requires civil servants to implement or manage it. Therefore, in the context of realizing an orderly population administration nationally, the Unitary State of the Republic of Indonesia which is based on the Pancasila and the 1945 Constitution of the Unitary State of the Republic of Indonesia is essentially obliged to provide protection and recognition of the determination of personal status and legal status for every population event and important incident experienced by residents and/or citizens of Indonesia who are outside the territory of the Unitary State of the Republic of Indonesia. Also, to improve population administration services in line with the guidance of population administration services in a professional manner, meeting information technology standards, dynamic, orderly, and nondiscriminatory in achieving minimum service standards leading to comprehensive prime services to address population problems, then Law Number 23 of 2006 concerning Population Administration and Amendments is formed. The amendment referred to is Law Number 24 of 2013 concerning Amendments to Law Number 2006 concerning Population Administration. ${ }^{1}$

\footnotetext{
${ }^{1}$ See Considerations Letter a, Letter B, Letter c, Law Number 24 of 2013 concerning
}

The provisions of Article 83A of Law Number 24 of 2013 concerning Amendments to Law Number 2006 concerning Population Administration (hereinafter referred to as the Population Administration Law), authorize the Minister to appoint and to dismiss officers of the work unit for population administrative affairs, as regulated in the Laws and Regulations this case is Ministerial Regulation Number 76 of 2015 concerning Appointment and Dismissal of Work Unit Officers for Population Administration Affairs in Provinces and Regencies/Cities (hereinafter referred to as Permendagri Number 76 of 2015). ${ }^{2}$

The provisions of Article 2 paragraph (1) and paragraph (2) Permendagri Number 76 of 2015 , state that the minister has the authority to appoint and to dismiss officers in the work units of population administration affairs in Provinces and Regencies/Cities. Regarding the provisions that authorize the Minister to appoint and to dismiss officers in the work unit of population administration affairs in the Province and Regency/City based on the Minister of Home Affairs Regulation Number 76 of 2015 above, in fact, at the Musi Rawas Utara Regency (Muratara) there are illegal inaugurations, in this case, related to the inauguration of the Head of the Department of Population and

Amendments to Law Number 2006 concerning Population Administration

${ }^{2}$ See considerations in letters $a$ and $b$ of Permendagri Number 76 of 2015. 
Civil Registration of Muratara Regency (Kadisdukcapil Kab. Muratara). As it is known that the officer, the Regent of Muratara Regency, Agus Yudiantoro, on Friday $12^{\text {th }}$ of February 2016, inaugurated 28 Echelon II, III officers, and IV before the inauguration of the Muratara Regent. For officers in the work unit for population administration affairs in province and regency/city is the authority of the Permendagri. Kadisdukcapil which was previously inaugurated by Komrol Sumai, then replaced by Sastra Manjani Kubitra, is invalid. Therefore it is returned to its original position. $^{3}$

Apart from the appointment and the dismissal of officers is not carried out by the Minister of Home Affairs, so there is no definitive juridical reason for the appointment and the dismissal of these officers. Even, the cancellation of the dismissal of Kadisdukcapil is not supported by an official letter of cancellation of the dismissal issued by the Minister of Home Affairs.

\section{Identification of Problems}

Identification of problem in this study are:

${ }^{3}$ Devi Suhartoni (deputy regent of muratara regency), 2016, "muratara officers who appointed by the officer, the Regent, H. Agus yudiantoro, are legitimate, except the head of the Kadisdukcapil", quoted on the website page ", https://gelagatsumsel.com/berita-2812-pejabatmuratara-yang-dilantik-pj-bupati-agus-yudiantorosah-keciali-kadisdukcapil,html, accessed on $20^{\text {th }}$ of March 2019, at 09.00 a.m. a. What is the mechanism for the appointment and the dismissal of officers in the Department of Population and Civil Registration at Muratara Regency based on Permendagri Number 76 of $2015 ?$

b. How is the legality of the appointment and the dismissal of officers in the Department of Population and Civil Registration carried out by the Regent of Muratara Regency?

\section{B. RESEARCH METHODS}

\section{Research Type}

The type of this research was normative legal research supported by legal materials sourced from field studies through interview with informant method. Through normative legal research, the certainty of legal principles related to legal arrangements regarding the implementation and legal consequences of violations of the mechanism of appointment and dismissal of officers in the work unit that handles administrative and population affairs in Muratara Regency based on Permendagri Number 76 of 2015 was explained and analyzed.

\section{Research Approach}

The approach used in this research was statutory (Statute Approach). The statutory approach was carried out to examine legal 
rules which are the focus of research. ${ }^{4}$ This approach was used to obtain a descriptive analysis of legal regulations that govern the mechanism for the appointment and the dismissal of officers in work units that handle administrative and population affairs based on Permendagri Number 76 of 2015.

\section{Types and Sources of Legal Materials}

Types and sources of data were obtained from primary data and secondary data. Primary data were data obtained from the first source ${ }^{5}$, or data obtained directly from the community through interviews, observation, and other tools. Meanwhile, secondary data, namely data obtained from or derived from library materials, includes documents, official documents, and report books, not limited by place and time. ${ }^{6}$ To solve legal issues prescriptively, data sources that can be differentiated into primary legal materials, secondary legal materials, and tertiary legal materials, namely:

a. Primary legal materials are binding legal materials ${ }^{7}$, consisting of :
1) The 1945 Constitution of the Republic of Indonesia (UUD 1945);
2) Law Number 24 of 2013 concerning Amendments to Law Number 23 of 2006

\footnotetext{
${ }^{4}$ Derita Prapti Rahayu, et al., 2020, Metode Penelitian Hukum, Yogyakarta: Thafa Media, p. 37.

${ }^{5}$ Ibid., P. 9.

${ }^{6}$ Ibid.

${ }^{7}$ Ibid., P. 83.
}

concerning Population

Administration (State

Gazette of the Republic of Indonesia of 2013 Number 232, Supplement to the State Gazette of the Republic of Indonesia Number 5475);

3) Law Number 5 of 2014 concerning Civil Servants (State Gazette of the Republic of Indonesia of 2014 Number 6, Supplement to the State Gazette of the Republic of Indonesia Number 5494); and

4) Regulation of the Minister of Home Affairs of the Republic of Indonesia Number 76 of 2015 concerning Appointment and Dismissal of Officers in Work Units that Handle Administrative and Population Affairs in Provinces and Regencies/Cities (State Gazette of the Republic of Indonesia of 2015 Number 1799).

b. Secondary legal material was legal materials used to provide explanations related to primary materials in the form of scientific papers, written literature by experts related to the problems in this study. ${ }^{8}$

c. Tertiary legal materials were materials that provide instructions and explanations for primary and secondary materials, 
including

dictionaries,

encyclopedias, and so on to

obtain the latest, relevant and upto-date information. ${ }^{9}$

\section{Legal Materials Collection}

The technique of collecting legal materials in this study was carried out through library research and field studies. A literature study was the technique of collecting legal material by conducting study studies of books, literature, notes, and reports that relate to the problem being solved. ${ }^{10}$ Apart from legal materials (primary, secondary, and tertiary), this research was also supported by primary (field) data or nonlegal data collected through field studies. Research into the field aimed to produce correlated primary data to support or complement the main data through the personal interview method (personal interviewing).

\section{Legal Material Processing}

Secondary data, which consists of primary, secondary, and tertiary legal materials, were then processed by carrying out an inventory and systematization laws and regulations that are relevant to legal issues. After obtaining the legal materials from the literature study, the legal materials were processed by systemization of the legal materials.

\footnotetext{
${ }^{9}$ Ibid., P. 84.

${ }^{10}$ Moh. Nazir, 2005, Metode Penelitian, Jakarta: Ghalia Indonesia, p. 27.
}

\section{Legal Material Analysis}

A qualitative juridical analysis was used to analyze legal materials, namely by describing, describing, outlining, and explaining quality legal materials in regular, sequential, non-overlapping, and effective sentences to facilitate understanding and interpretation of legal materials. ${ }^{11}$

\section{RESULTS AND DISCUSSION}

1. The mechanism for Appointment and Dismissal of Officers in Department of Population and Civil Registration at Muratara Regency based on Permendagri Number 76 of 2015

Concerning the provisions in the Population Administration Law and the implementing regulations of Permendagri Number 76 of 2015, namely which authorizes the Minister to appoint and to dismiss Officers in Work Units that handle Population Administration affairs in regency/city, in this case, the Head of Department, in fact, in 2016, Head of Department of Population and Civil Registration of Muratara Regency (Kadisdukcapil of Muratara Regency) Sastra Manjani Kubitra was appointed by the Regent of Muratara, where previously the Regent dismissed the Kadisdukcapil of Muratara Regency, Komrol Sumai. Of course, normatively, the Regent's actions exceeded or fell outside his authority, so that

\footnotetext{
${ }^{11}$ Ibid., p. 127.
} 
this became pros and cons therefore, in the end, Komrol Sumai was returned to his original position as Kadisdukcapil of Muratara Regency.

The regent's actions that violate his authority do not reflect himself as a good public officer, because the appointment and assignment of him to occupy a certain officer or position in a public institution do not uphold the ethics inherent in his position as a form of moral responsibility in maintaining the spirit of his position. ${ }^{12}$

In the context of a rule of law, Indonesia is a country based on law, a democratic country (sovereignty of the people), based on one God and social justice, and contains the principle of legality (legal certainty) in both formal and material terms. ${ }^{13}$ Regarding the principle of legality, it means that the rule of law is closely related to the concept of legal certainty, that regulations are made in writing in the form of statutory regulations.

The concept of a rule of law and the principle of legality is associated with this study, that the provisions of Article 83A paragraph (2) of the Population Administration Law and the provisions of Article 6 paragraph (1) Permendagri 76/2015 explicitly provides legal certainty that

${ }^{12}$ Adies Kadir, 2018, Menjaga Moral Pejabat Publik, South Jakarta: PT Semesta Merdeka Utama, p. 21.

${ }^{13}$ Juniarso Ridwan and Achmad Sodik Sudrajat, 2019, Hukum Administrasi Negara dan Kebijakan Layanan Publik, Bandung: Nuansa Cendekia, p. 34. structural officers in the work unit that handle Population Administration Affairs in the regency are appointed and dismissed by the Minister upon the recommendation of the Regent. Furthermore, the Primary High Officers in the work unit that handle Population Administration Affairs in Regency, in this case, the Head of Department, are appointed and dismissed by the Minister upon the Regent's suggestion. Therefore, the appointment of Kadisdukcapil Muratara in 2016 by the Regent is a form of violations of authority and law, because the authority is not within his authority and legally clearly violates the provisions of the Population Administration Law and Permendagri 76/2015.

2. The Legality of the Appointment and the Dismissal of Officers in Department of Population and Civil Registration Carried Out by the Regent of Muratara Regency

In 2016, Kadisdukcapil of Muratara Regency, Komrol Sumai is dismissed by the Regent and then appointed a new one, Sastra Manjani Kubitra, then the Regent's actions are beyond his authority because it should be the authority of the Minister. ${ }^{14}$ The action outside the regent's authority shows that there is violation administration, which means a

14 The results of an interview with Aan Andrian, as the Head of the Population and Civil Registration Office of Musi Rawas Utara Regency, on March $10^{\text {th }}, 2021$. 
practice that deviates from administrative ethics, or an administrative practice that distracts from achieving administrative goals through abuse of authority and procedural deviations. ${ }^{15}$ The authority to appoint and to dismiss Kadisdukcapil is only attributive to the authority of the Minister. Even in the source of the delegation's authority, Permendagri Number 76 of 2015 does not mention the Regent regarding the authority to appoint and dismiss officials. In fact, in the source of delegation's authority, the provisions of Article 2 paragraph

Permendagri Number 76 of 2015 only give delegation authority to the Director-General of Population and Civil Registration in the appointment and dismissal of officers in Work Units in charge of Population Administration affairs consisting of Administrator and Supervisory Positions. As for the Primary High Leadership Position, it becomes the authority of the Minister.

Based on the provisions of Article 6 Permendagri Number 76 of 2015, the appointment of Kadisdukcapil Muratara in 2016 by the Regent is invalid, because the Regent is only authorized to propose three names of candidate Officials for the Minister to determine one of the proposed officers. Furthermore, of course, the provisions of Article 8 regarding the requirements for the

\footnotetext{
${ }^{15}$ Joko Widodo, quoted in: Ridwan and Nurmalita Ayuningtyas Harahap, 2018, Hukum Kepegawaian, Yogyakarta: UII Press, p. 141-142.
}

appointment of Permendagri Number 76 of 2015 have never been implemented, because the Regent only immediately appoints a new Kadisdukcapil in such away. It should be, the Muratara District Personnel and Human Resources Development Agency (BKPSDM) should have known and followed up on this problem because the inauguration procedure was the authority of BKPSDM and it should also play an active role technically and administratively including giving views to the Regent at that time. ${ }^{16}$

The provisions of Article 11 paragraph (1) and paragraph (2) Permendagri Number 76 of 2015, concerning the dismissal of the old Kadisdukcapil of Muratara Regency in 2016 by the Regent, did not find any reason as to why the previous Kadisdukcapil should be dismissed. This is in line with the provisions of Article 12 paragraph (2), paragraph (3), and paragraph

Permendagri Number 76 of 2015 which mandates that the dismissal of officials in the district is proposed by the regent to the Minister through the governor along with reasons and considerations for their dismissal to be stipulated by a Ministerial Decree, at the same time including the previous proposal for the appointment of the Officer. ${ }^{17}$

${ }^{16}$ The results of an interview with Ralin Jufri, as the Head of the Personnel and Human Resources Development Agency of Musi Rawas Utara Regency, on March $9^{\text {th }}, 2021$.

${ }^{17}$ The results of an interview with Ralin Jufri, as the Head of the Personnel and Human Resources 
The Regent's action that does not give reasons for dismissal or appointment of office is of course a violation of professionalism in professional ethics, while professional ethics is very necessary so that irregularities that cause discrepancies do not occur. Professionalism is very important in a job in a position so that if a profession is without ethics, there will be irregularities that result in injustice and public distrust. ${ }^{18}$

The cancellation as described above, should not be done considering the potential for the presumption that there is a clash of neutrality and partiality values, or in this case, actions outside the authority of the Regent are closer to taking sides for both collegial colleagues or personal and group interests. Therefore, the Regent as an administrator in decision making should demand that he act rationally. That he must have enough data and information, and then be able to process them and conclude them to make decisions. If it is not, of course, the administrator tends to choose what he can do with the support of what his institution has, or choose according to his preferences. ${ }^{19}$

\section{CLOSING}

Development Agency of Musi Rawas Utara Regency, on March $9^{\text {th }}, 2021$.

${ }^{18}$ Serlika Aprita, 2020, Etika Profesi Hukum, Bandung: PT Refika Aditama, p. 18.

${ }^{19}$ Yeremias T. Keban, 2019, Enam

Dimensi Strategies Administrasi Publik:

Konsep,Teori, dan Isu, Yogyakarta: Gava Media, p. 27.

\section{Conclusion}

The conclusions that can be drawn from this research are:

a. The mechanism for appointing and dismissing Officials at the Population and Civil Registration Service (Disdukcapil) in the Muratara Regency Government based on Permendagri Number 76 of 2015 is under the authority of the Minister of Home Affairs. The regent is only authorized to make proposals for appointment (and dismissal) through the Governor and includes proposals for three names of candidates for appointment, for which one of them is chosen by the Minister, stipulated by a Ministerial Decree, and appointed.

b. The validity of the Appointment and Dismissal of Officials at the Dukcapil Service is a material legal flaw because in the process of issuing a Decree $(S K)$ it is not in accordance with its authority, procedure, and substance.

\section{Suggestion}

Suggestions that can be put forward in this research are: 
a. To the Central Government and Regional Governments, it is necessary to strengthen government organs that supervise regional heads over the implementation of their duties and authorities which have the potential for violations of authority either due to administrative negligence or deliberate intent which was suspected to be motivated by subjective interests or personal and group interests in around regional heads who intervene with political or collegial pressure.

b. To regional heads, be they Governors, Regents, or Mayors, to always be careful in carrying out their duties and authorities based solely on the mandate set out in statutory regulations. This is so to avoid legal consequences that can occur, especially regarding accountability from the side of administration and code of ethics.

c. To the District Personnel and Human Resources Development Agency, to always coordinate and communicate with the Regent, especially in terms of strengthening insight and understanding of legal rules and mechanisms for the appointment and dismissal of officials, especially in their authority in the procedures for the inauguration.

\section{REFERENCES \\ Books}

Adies Kadir, 2018, Menjaga Moral Pejabat Publik, Jakarta Selatan : PT Semesta Merdeka Utama.

Derita Prapti Rahayu, dkk., 2020, Metode Penelitian Hukum, Yogyakarta : Thafa Media.

Dominikus Rato, 2010, Filsafat Hukum Mencari : Memahami dan Memahami Hukum, Yogyakarta : Laksbang Pressindo.

Juniarso Ridwan dan Achmad Sodik Sudrajat, 2019, Hukum Administrasi Negara dan Kebijakan Layanan Publik, Bandung : Nuansa Cendekia.

Peter Mahmud Marzuki, 2005, Penelitian Hukum, Jakarta : Kencana Prenada Media Group.

Philipus M. Hadjon, 2005, Pengantar Hukum Administrasi Indonesia, Yogyakarta : Gadjah Mada University Press.

Ridwan dan Nurmalita Ayuningtyas Harahap, 2018, Hukum Kepegawaian, Yogyakarta : UII Press.

Sahya Anggara, 2012, Ilmu Administrasi Negara, Bandung: Pustaka Setia.

Sastra Djatmika dan Marsono, 1995, Hukum Kepegawaian di indonesia, Jakarta : Djambatan.

Serlika Aprita, 2020, Etika Profesi Hukum, Bandung : PT Refika Aditama.

\section{Journal}

Irwansyah Putra dan Zaid Afif, "Peran Badan kepegawaian Daerah Dalam Pemberhentian Aparatur Sipil Negara 
Akibat Melakukan Tindak Pidana Dalam Jabatan (Studi Di Kantor Badan Kepegawaian Daerah Kota Tanjung Balai", Jurnal Tectum, Vol. 2, No. 1, November 2020, e-ISSN : 2715-2677, Fakultas Hukum Universitas Asahan Kisaran Sumatera Utara.

Inong, "Hak Konstitusional Pegawai Negeri Sipil (PNS) dalam Pencalonan Sebagai Kepala Daerah", Jurnal Katalogis, Vol. 3, No. 2, November 2015, e-ISSN : 2302-2019, Magister Ilmu Hukum Pascasarjana Universitas Tadulako.

\section{Regulation}

Undang-Undang Dasar Negara Republik Indonesia Tahun 1945 (UUD 1945)

Undang-Undang Nomor 24 Tahun 2013 tentang Perubahan atas UndangUndang Nomor 23 Tahun 2006 Tentang Administrasi Kependudukan

Undang-Undang Nomor 5 Tahun 2014 tentang Aparatur Sipil

Peraturan Menteri Dalam Negeri Republik Indonesia Nomor 76 Tahun 2015 tentang Pengangkatan dan Pemberhentian Pejabat Pada Unit Kerja yang Menangani Urusan Administrasi dan Kependudukan di Provinsi dan Kabupaten/Kota

\section{Website}

Devi Suhartoni (Wakil Bupati Kabupaten Muratara), 2016, "Pejabat Muratara yang Dilantik PJ Bupati H. Agus Yudiantoro Sah, Kecuali Kadisdukcapil", dikutip pada laman website", https://gelagatsumsel.com/berita-2812pejabat-muratara-yang-dilantik-pjbupati-agus-yudiantoro-sah-kecialikadisdukcapil,html, diakses pada tanggal 20 maret 2019, pukul 09.00 WIB.

Joseph Raz, 2012, "Legal Validity", dikutip pada laman website : https://oxford.universitypressscholarshi p.com/view/10.1093/acprof:oso/97801 98253457.001.0001/acprof9780198253457-chapter-8, diakses pada tanggal 10 Maret 2021.

Kamus Besar Bahasa Indonesia, tanpa tahun, "Definisi Absah", dikutip pada laman website : https://kbbi.web.id/absah diakses pada tanggal 10 Maret 2021. 